\title{
Rockfill embankment construction on tailings — realistic, cost-effective and reliable application at Xstrata, Mount Isa, Australia
}

\author{
G. Reinke Xstrata Copper, Australia
}

A. Soliman Xstrata Zinc, Australia

A. Purkis Xstrata Copper, Australia

\begin{abstract}
Mount Isa Mines Ltd (MIM), Queensland, Australia, was formed in 1923 when a discovery of silver lead ore was made. At the beginning, the production was focused on lead-zinc-silver mined underground with little focus on copper. Currently, copper is mined in two underground mines and lead-zinc is mined in two open cuts and an underground mine. It was not until June 2003 that Xstrata officially took control of Mount Isa Mines Ltd. In general terms, the geology of the mining area is comprised mainly of Urquhart shale and Spear siltstone.

The history of the Xstrata Mount Isa Mines tailings storage facility (TSF) stretches back to the 1930s with the construction of the No. 1 tailings facility. The current tailings storage facility has two existing and five decommissioned dams. The existing dams, Nos. 7 and 8 comprise five external walls with nine internal groynes covering an estimated area of 1,300 hectares. Current operational capacity, as of Q2 2009, was approximately 16 million cubic metres with more capacity identified in late 2009 with the utilisation of the western and southern evaporation ponds.
\end{abstract}

The current tailings strategy is to continue depositing wet tailings via a gravity outfall line to two of the existing tailings dams, and to also raise dam walls and groynes as they become necessary. The existing strategy proved to be usable for 2-4 years by which time an alternative outfall should be established. Although a conventional geotechnical design was used to construct a groyne on the tailings of one of the tailings dams, recently the groyne has been constructed using the 'ice-breaker' technique utilising the waste rock available from the nearest open cut to the tailings area.

The lesson learnt from the success of the construction trial of the groyne will be applied next year to the proposed high groyne on the tailings as part of the future tailings placement. By doing so, the life of the existing tailings dams will be extended by postponing the need for a pumped outfall, and hence reducing future operation costs. This is in addition to the benefit of consuming waste rock close to the source, resulting in reduced operating costs to the open pit.

The paper presents various aspects of the project. These include a brief on the current and future tailings strategy, the proposed conventional geotechnical design and the economic and safe construction technique used instead to construct the groyne. A summary of the geotechnical modelling results are also presented. To demonstrate the financial benefit, the paper provides cost and time comparison between the conventional design, if adopted for construction, and the realistic and successful construction trial approach.

\section{Introduction}

Xstrata Mount Isa Mines commenced depositing tails in the early 1930s with the construction of the No. 1 tailings storage facility (TSF). The continued life of the mine has resulted in several tailings dam having been constructed and managed over the lease's 85 year history. Currently Xstrata Mount Isa Mines actively manages two 'live' dams using a sub-aerial method of deposition and in line with the guidelines of the Queensland Department of Environment and Resources Management (DERM). All decommissioned dams are being continually monitored as they are covered by a waste rock dump from the nearest open cut known as Black Star Open Cut (BSOC) which is a zinc mine. 
The 'live' TSF No. 7 and 8 comprise five external walls with nine internal groynes, the terminology designates the usage of the asset a 'groyne' is within the confines of the dam and a 'wall' is external part of the dam boundary, covering an estimated area of 1,300 hectares. An aerial photo of the existing tailings facility is shown in Figure 1. Current operational capacity, as of Q2 2009, was approximately 16 million $\mathrm{m}^{3}$ with more capacity identified in late 2009 with the utilisation of the western and southern evaporation ponds.

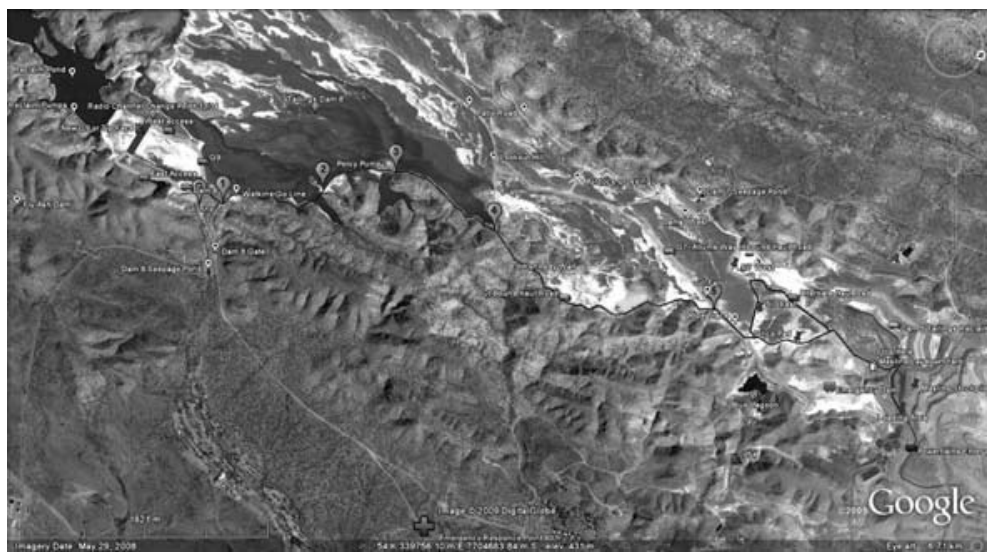

Figure 1 Tailings storage general layout (north to left border)

The current tailings strategy is to continue depositing wet tailings sub-aerially via a gravity outfall line to the existing tailings dams, and to raise dam walls and groynes as they become necessary. The existing strategy will prove to be usable for two to four years by which time an alternative outfall should be established. A proposed outfall groyne at tailings TSF No. 5 is shown in Figure 2. The northern end of the groyne is approximately $35 \mathrm{~m}$ high, and the southern end is approximately $15 \mathrm{~m}$ high.

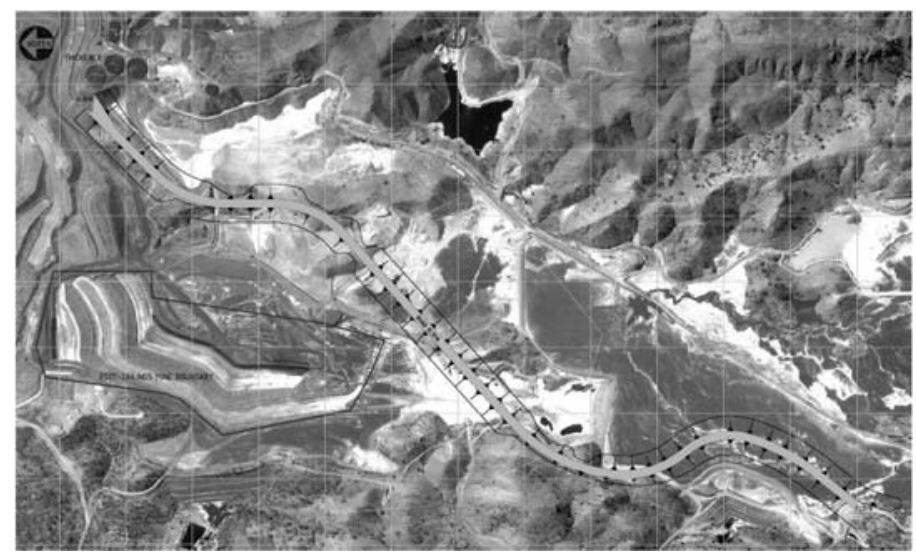

Figure 2 Proposed outfall groyne tailings TSF No. 5

\section{Geotechnical modelling of rockfill on tailings}

In order to assist in understanding the behaviour of the tailings during placement of a rockfill embankment (or waste rock dump), numerical modelling has been undertaken.

The most common methods of rockfill placement are the layer-dumped and end-dump methods. Construction of the former method is usually carried out from the bottom up on layers or lifts while the enddump method is formed by advancing the dump face of full height in a controlled approach. A sketch of the two methods is shown in Figure 3. In the mining environments, the end-dump method is commonly used. The method comprises dumping at the tip head and a dozing operation. The two-dimensional elasto-plastic finite element stress analysis program Phase ${ }^{2} 6.0$ (Rocscience, 2005) has been used in the modelling. Soliman (2010) presented full details of the simulation. 

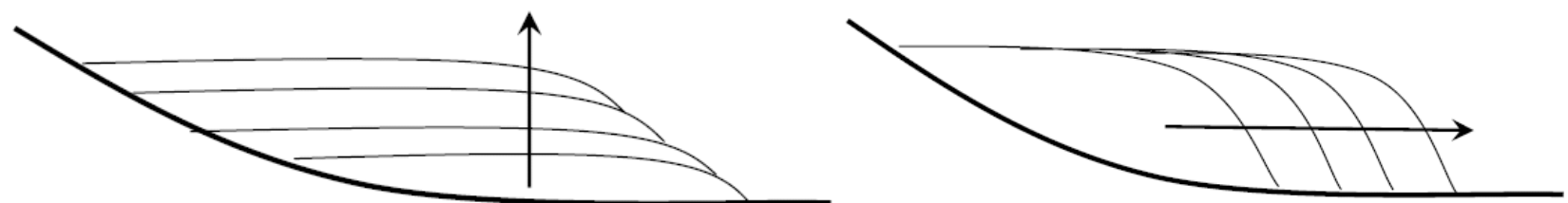

Figure 3 Waste rock dumping methods (layers left sketch, end-dumping right sketch)

In an attempt to simulate the construction process of the rockfill embankment, the modelling exercise was based principally on the measured in situ strength parameters of the tailings at tailings TSF No. 5 (Soliman, 2008), a $35 \mathrm{~m}$ high rockfill embankment on $20 \mathrm{~m}$ thick tailings deposited on the bedrock and groundwater table located at approximately $5 \mathrm{~m}$ below the tailings surface. The geotechnical investigation which was carried out to characterise the subsurface conditions of the tailings at the site included cone penetration test (CPT), pore pressure dissipation test (PPDT) and dilatometer test (DMT). In addition, a liquefaction potential assessment was also carried out. Due to the paper size limitations combined with the fact that the aim of the paper is to present a case study guided by numerical modelling simulation, the outcome of the 2008 in situ investigation is not discussed in this paper. However, briefly the estimated friction angle was in the range of $15-30^{\circ}$ and undrained shear strength $\left(\mathrm{C}_{\mathrm{u}}\right)$ of $10-20 \mathrm{kPa}$.

To be able to carry out the numerical modelling simulation, Caldwell (1985), Soliman (2008) and Golder (2009) were consulted to adopt the most relevant and possibly lowest material strength and deformation properties (i.e. worst case scenario) required. The material properties that were adopted are given in Table 1.

Table 1 Adopted material parameters

\begin{tabular}{llllll}
\hline Material & $\begin{array}{l}\text { Young's } \\
\text { Modulus (kPa) }\end{array}$ & $\begin{array}{l}\text { Poisson's } \\
\text { Ratio }\end{array}$ & $\begin{array}{l}\text { Unit } \\
\text { Weight } \\
\left(\mathbf{k N / m ^ { 3 } )}\right.\end{array}$ & & \multicolumn{2}{c}{\begin{tabular}{l} 
Mohr-Coulomb Parameters \\
\cline { 5 - 6 }
\end{tabular}} & & 0.3 & 17 & - & 15 \\
\hline Tailings (drained) & 600 & 0.49 & 17 & 10 & 0 \\
Tailings (undrained) & 690 & 0.35 & 19 & - & 40 \\
Rockfill & 500,000 & & & & Friction Angle ( \\
\hline
\end{tabular}

\subsection{Modelling results}

The prediction of the rockfill embankment and tailings performance during the construction of the embankment is discussed in the following three sub-sections. To facilitate and simplify the presentation of the results, the contour plots of the total displacement only are displayed.

\subsubsection{Layer-dumped method}

For the purpose of the modelling, the rockfill embankment was constructed on three lifts of uniform thickness. Figure 4 shows the model of the layer-dumped method. 


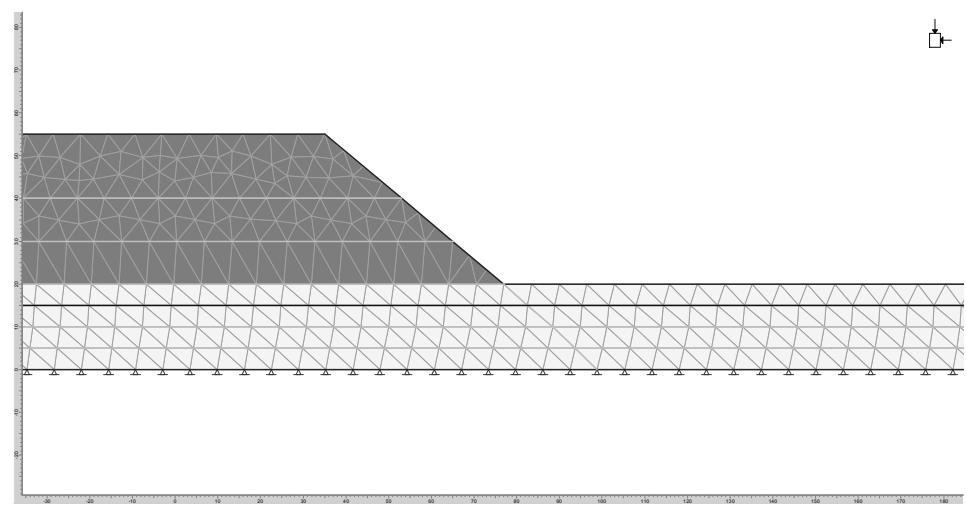

\section{Figure 4 Layer-dumped model}

Figures 5 and 6 present the predicted total displacement that will result from placing the first and final rockfill lifts, respectively. It should be noted that the numerical stability of the problem could not be achieved primarily due to the low strength of the tailings (i.e. $\mathrm{C}_{u}$ of $10 \mathrm{KPa}$ ) which indicate definite failure of the rockfill embankment. For the sake of completion of the numerical simulation, $\mathrm{C}_{\mathrm{u}}$ was gradually increased to $100 \mathrm{kPa}$ to achieve numerical stability of the problem to allow visualisation of the deformation and failure mechanism.

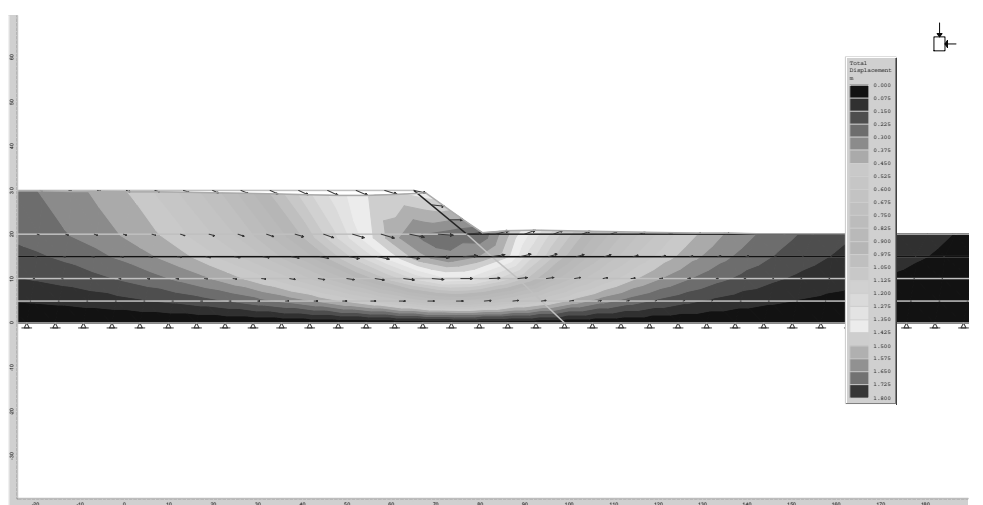

Figure 5 First lift - layer-dumped method - total displacement contour plot

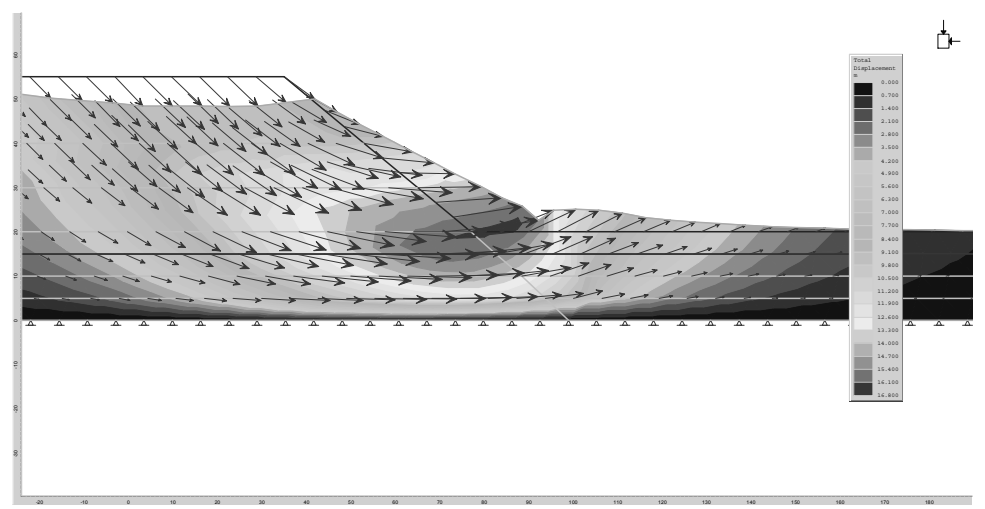

Figure 6 Third lift - layer-dumped method - total displacement contour plot

Figures 5 and 6 illustrate that a major failure is imminent as indicated by the large deformation of the rockfill and tailings. The total displacement plots also demonstrate that the failure will most likely be initiated during the placement of the first lift or at some stage during construction of the embankment. The results of the modelling of the layer-dumped indicate that placing the embankment on the surface of the tailings with no allowance for rock penetration (i.e. reality) or additional support such as geotextile is not physically and/or 
practically possible due to the fact that the tailings have no adequate strength to sustain the rockfill embankment load.

It should be mentioned that, during placement of the rockfill, 'mud wave' will most certain take place as shown in the figures. The 'mud wave' or surface heave is an indication of simultaneous tailings displacement and bearing failure due to the load imposed by the rock fill as construction progresses. It is anticipated that the tailings may heave to up to approximately $5 \mathrm{~m}$. The 'mud wave' may reach its peak at approximately 20-30 m away from the toe of the rockfill, then diminishing gradually beyond this distance.

\subsubsection{End-dumping method}

Figure 7 shows the model of the end-dump method. In this method, the dump face advances forward once the full height of the dump has been reached. In the same manner as mentioned in Section 4.1.1, $\mathrm{C}_{\mathrm{u}}$ was increased to $100 \mathrm{kPa}$ to achieve numerical stability of the problem to allow visualisation of the deformation and failure mechanism.

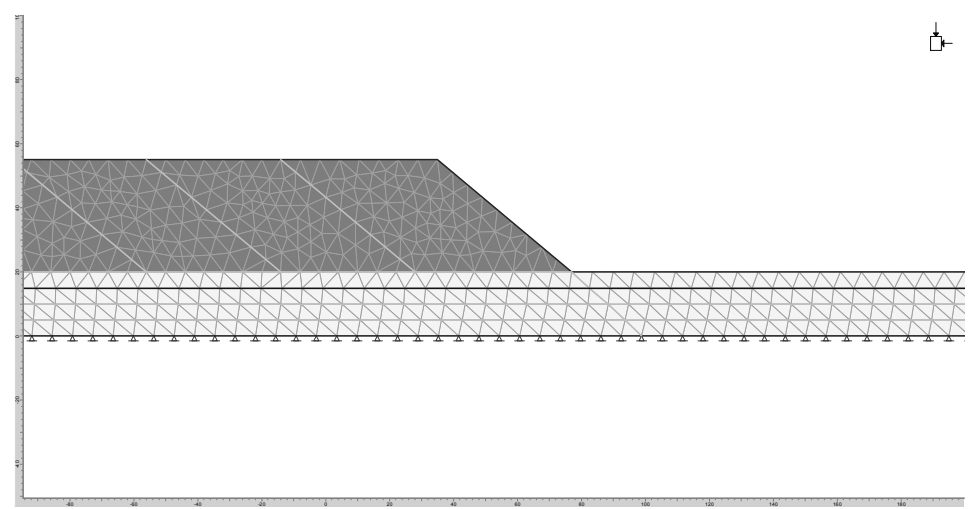

\section{Figure 7 End-dumping model}

Contour plots of the total displacement for a number of consecutive rock dump faces are shown in Figure 8 . The figure indicates that failure of the tailings will occur as the dump face advances. The figure shows also that the 'mud wave' moves forward concurrently with the dump face. The dimensions of the 'mud wave' appear to be similar to that of the layer-dumped method of approximately $5 \mathrm{~m}$ heave at approximately 20-30 $\mathrm{m}$ from the toe.

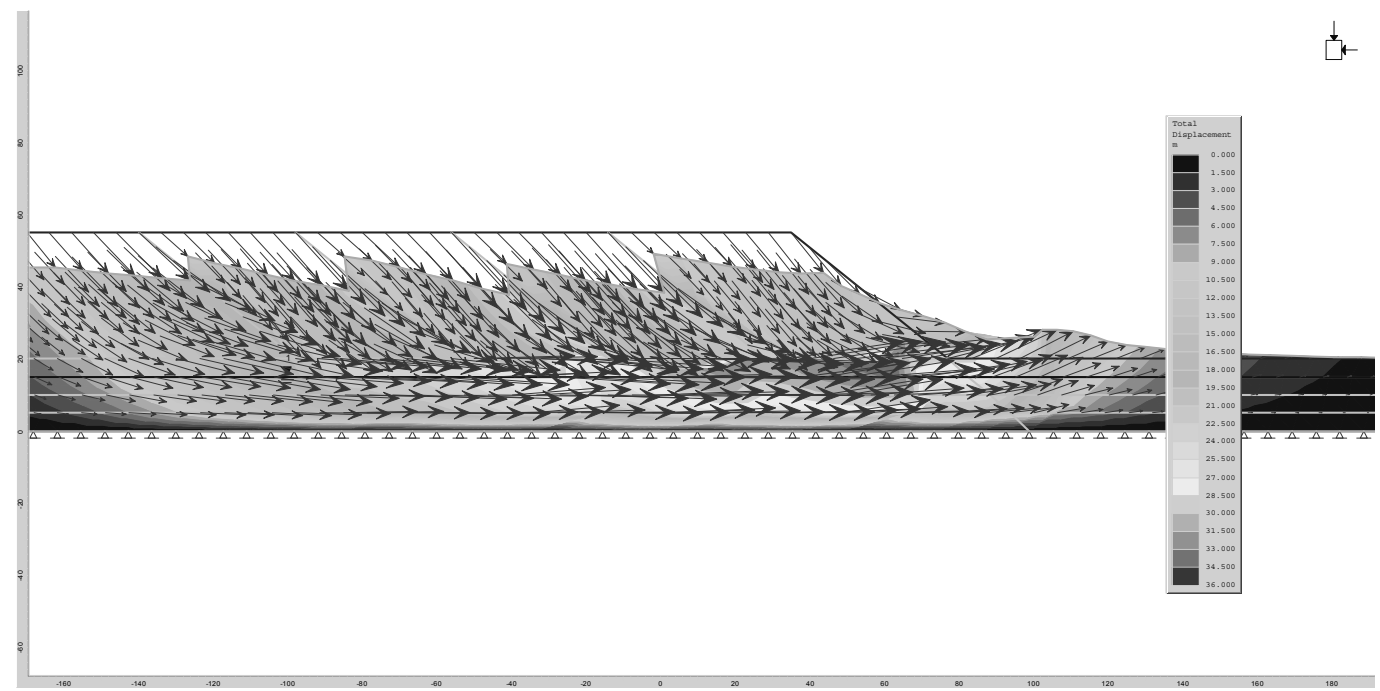

Figure 8 End-dumping method - total displacement contour plot 


\subsubsection{Stable rockfill embankment simulation}

In an attempt to replicate to some degree (within the limitations of the modelling software) the real construction operation of the rockfill embankment, two additional scenarios were carried out allowing rockfill penetration into the tailings. As the depth of penetration cannot be estimated properly, the additional scenarios were as below.

Scenario 1 Three-quarter of the tailings thickness $-15 \mathrm{~m}$ rockfill penetration. As per Table $1, \mathrm{C}_{\mathrm{u}}$ of $10 \mathrm{kPa}$ was used (i.e. no artificial increase).

Scenario 2 Full thickness of the tailings $-20 \mathrm{~m}$ rockfill penetration.

The contour plots of the total displacement are shown in Figures 9 to 10 for the two scenarios respectively. Comparison of the two figures reveals that for the embankment to be built to the full height of $35 \mathrm{~m}$, deep penetration of the rockfill is required. The $15 \mathrm{~m}$ rockfill penetration into the tailings appeared not to be adequate to support the embankment load as indicated by the large deformation and potential failure (Figure 9). Scenario 2 is considered the most realistic one, and is likely to occur if a $35 \mathrm{~m}$ high rockfill embankment is to be built. It should be noted that the total displacement shown in Figure 10 is the deformation of the embankment itself as it is founded on the in situ rock.

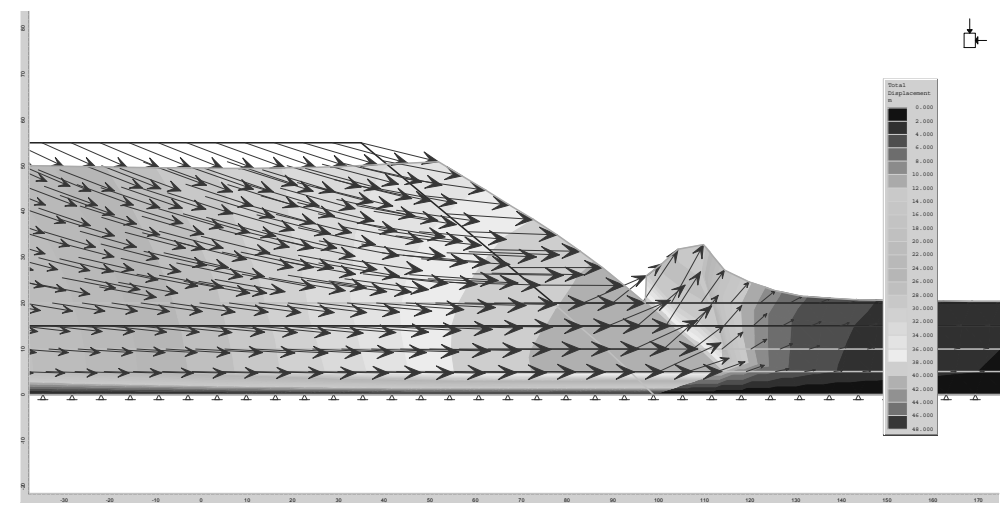

Figure 9 Rockfill: $15 \mathrm{~m}$ penetration (3/4 tailings thickness)

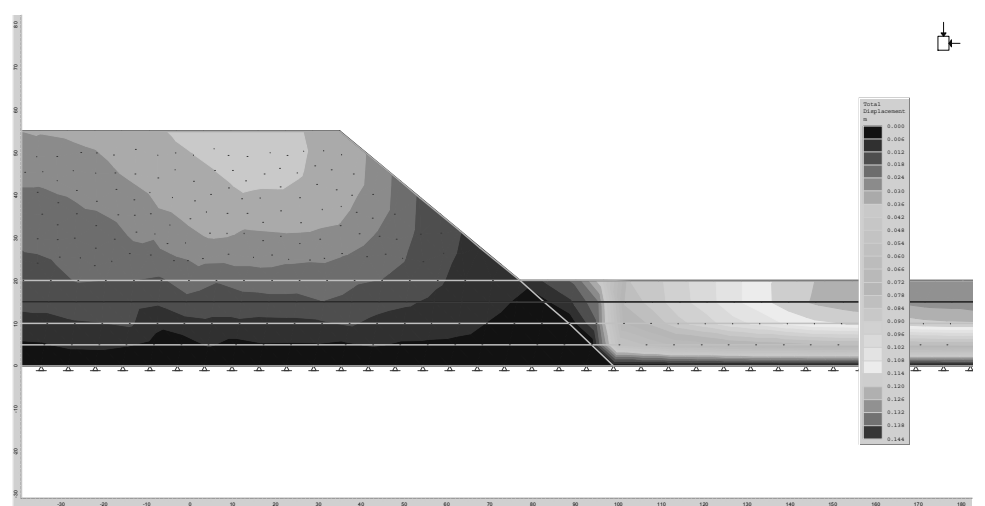

Figure 10 Rockfill: $20 \mathrm{~m}$ penetration (full tailings thickness)

\section{Construction trial on tailings - groyne No. 9}

Recently at tailings TSF No. 8, a groyne named No. 9 was constructed using the end-dumping method (i.e. ice breaker). A plan showing the location of the groyne is given in Figure 11. The height of the groyne is approximately $2.3 \mathrm{~m}$ above the tailings surface. The tailings TSF No. 8 wall is currently at Stage 3 height (RL 3479) which was designed and completed in the early 1990s. This wall was raised using the Stage 2 wall of the late 1970s as its foundation. An earlier Stage 1 wall was inundated with the construction of Stage 2 as issue with ground water penetration deemed it unsuitable. Tailings TSF No. 8 wall is to be raised further to Stage 4 and Stage 5 RL's using Stage 3 as the foundation. 


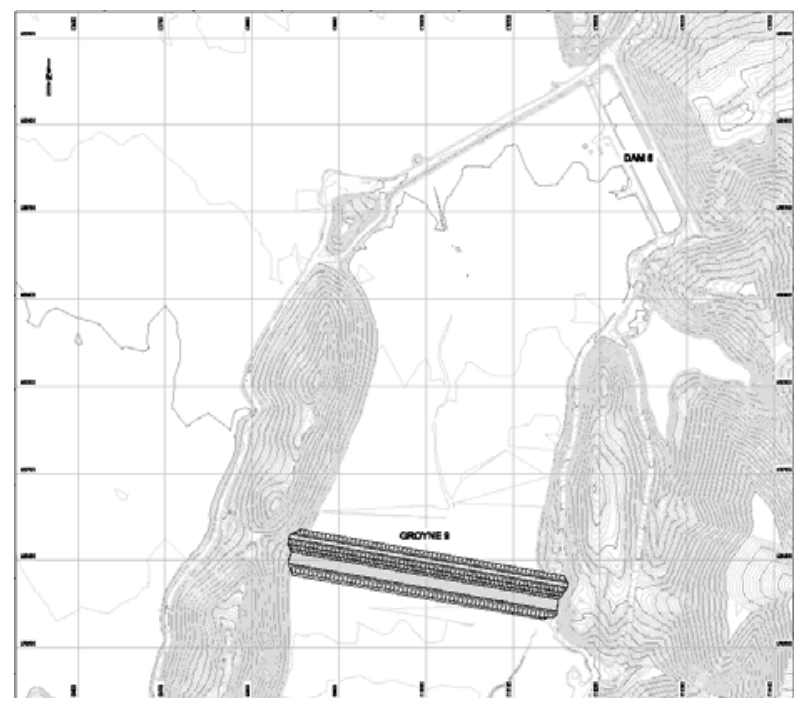

Figure 11 Location of groyne No. 9 - tailings TSF No. 8

The original No. 9 was pushed as construction access to a trafficable decant located to the west of the tailings TSF No. 8 wall. This road then became a barrier utilised to separate the tailings and process water dam. To utilise further space behind the tailings dam wall, and to aid in the further stabilisation of the dam when Stage 4 (RL 3481) and Stage 5 (RL 3483.5) have been completed, a decision was made to build the groyne (No. 9) further downstream.

\subsection{Original groyne No. 9 design and construction}

Initially, conventional design was made completed to build and raise the groyne on stages using the upstream construction method. A cross-section of the starter groyne is shown in Figure 12.

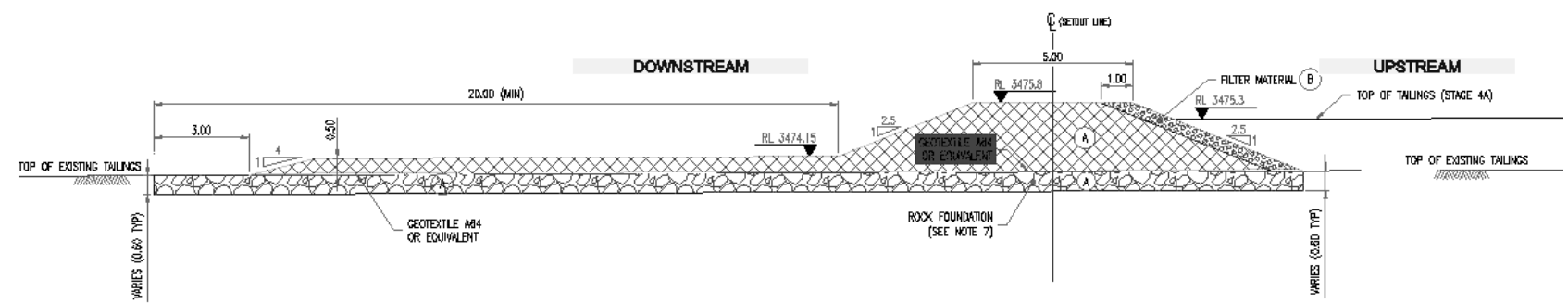

Figure 12 Original cross-section - groyne No. 9

Estimates were sorted from local civil contractors to construct the groyne within a four week window. The first estimate supplied as per the specifications was approximately AU\$560,000. The quantities of the initial estimate of the original design are given in Table 2. 
Table 2 Proposed design - initial estimate

\begin{tabular}{lcc}
\hline Description & Unit & Quantity \\
\hline Foundation & & \\
Stripping & $\mathrm{m}^{2}$ & 500 \\
Supply and place Zone A rock & $\mathrm{m}^{3}$ & 6,250 \\
Supply and place A64 geotextile or equivalent & $\mathrm{m}^{2}$ & 9,520 \\
Groyne Earthworks & & \\
Supply and place Zone A rock & $\mathrm{m}^{3}$ & 8,410 \\
\hline
\end{tabular}

Various slope stability, seepage, and settlement analyses were carried out indicating that the staged groyne is stable subject to various a ranges of recommendations which included placing geotextile on the tailings surface, platform preparation, placing the fill on lifts and installation of monitoring systems. The groyne was to be completed in the following manner.

- The base or foundation was to be laid out to give a solid work platform, and the geotextile to be laid over the solid platform.

- Once the geotextile was in place, the scour protection was to be laid out.

- The groyne probably would be built across the front edge of the completed foundation.

- Then finally the filter layer would be placed.

Following assessing an assessment of the first estimate a decision was made to consider using ROM instead of the specified zone materials. An assessment was made showing that the material change would not impact the functioning of the groyne, but may allow more tails egress than previously specified. A second estimate was sorted prepared using ROM instead of screened rock. It was estimated to be cost AU $\$ 460,000$ and still completed within four weeks.

As the tailings facility has narrow access roads, the use of machines larger than a Caterpillar 740s were was not considered. A cost comparison between 10 tonne dump trucks, more commonly known as body trucks, and Caterpillar 740s was carried out on a tonnes per dollar basis and Caterpillar 740s were deemed a more appropriate solution.

It was estimated that at the finished level the groyne would use $15,280 \mathrm{~m}^{3}$ of rock. For the purpose of constructing the wall this meant moving 30,560 tonnes of ROM rock $8 \mathrm{~km}$ from the loading point to the groyne.

An in-house estimate utilising the information at hand assumed that the project would take up to 15 days barring incident or delays. The tailings area has a maximum speed limit of $40 \mathrm{~km} / \mathrm{hour}$ so it was estimated that 1.5 trips an hour per truck could be carried out, allowing for loading and unloading.

With a truck route planned, it was estimated that the completion of the project within 15 days is possible, barring delays, using four Caterpillar 740s and a Komatsu Loader and Caterpillar D9. Transport and placement were estimated to cost AU $\$ 320,000.00$ for 20 days with ancillary costs for dust suppression, road grading, fuel and surveying added another AU $\$ 100,000.00$ to the estimate. The estimated cost to construct the groyne using ROM was AU\$420,000.

The total estimated quantities to construct the groyne as per the original design are given in Table 3. 
Table 3 Total estimated quantities

\begin{tabular}{lcc}
\hline Description & Unit & Quantity \\
\hline Stripping & $\mathrm{m}^{2}$ & 500 \\
Supply and place Zone A rock & $\mathrm{m}^{3}$ & 26,280 \\
\hline
\end{tabular}

\subsection{Implemented end-dumping construction method}

Initially a compacted layer was laid out across the base to form the solid work platform as per the original design (Section 3.1). However, construction issues with this initial tactic became evident immediately. When trying to establish the foundation layer, large penetrations of tails occurred and the stability around these areas was questionable as shown in Figure 13. As a result of internal discussions, a decision was made to construct the groyne using the 'ice-breaker' approach to displace and replace the tailings by end-dumping.

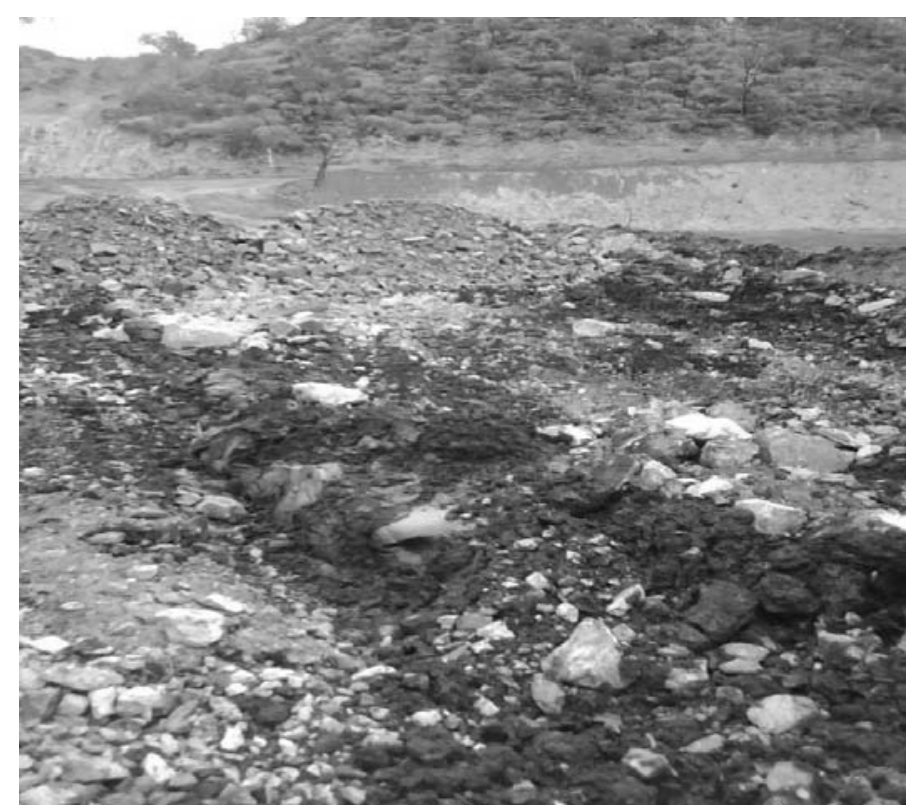

Figure 13 Typical penetration of tailings - push into tails

The rock used for construction was sourced out of rock waste from the Black Star Open Cut. The rock waste was composed mainly of siltstone and shale. The sourced rock was ROM and the only monitoring was carried out by the operators placing aside rock considered too large to be safely transported by the Caterpillar 740 s. A typical load of ROM is pictured in Figure 14 sized against a hard hat. There was a previously sorted pile of rock fines (under $200 \mathrm{~mm}$ ) that were used to cap the groyne to limit tyre issues on the trucks.

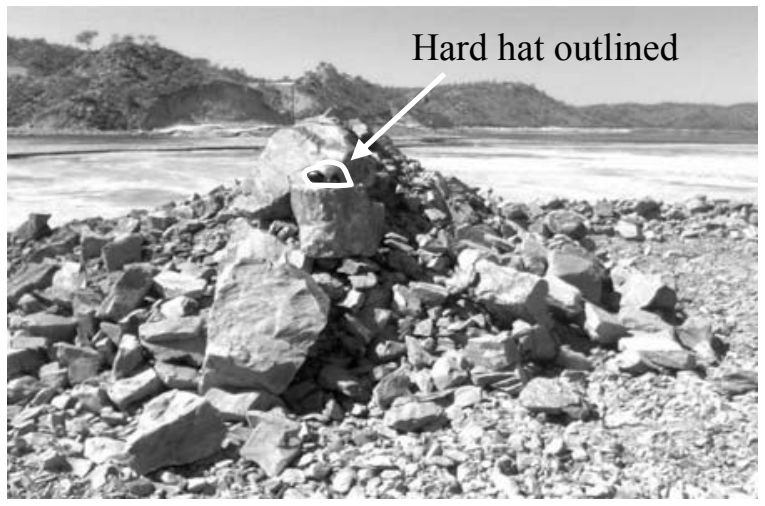

Figure 14 ROM from BSOC (hard hat for scale) 
The final cross-section of the groyne is shown in Figure 15. The cross-section does not include the region of the tailings which were displaced by rocks (e.g. subsurface cross-section).

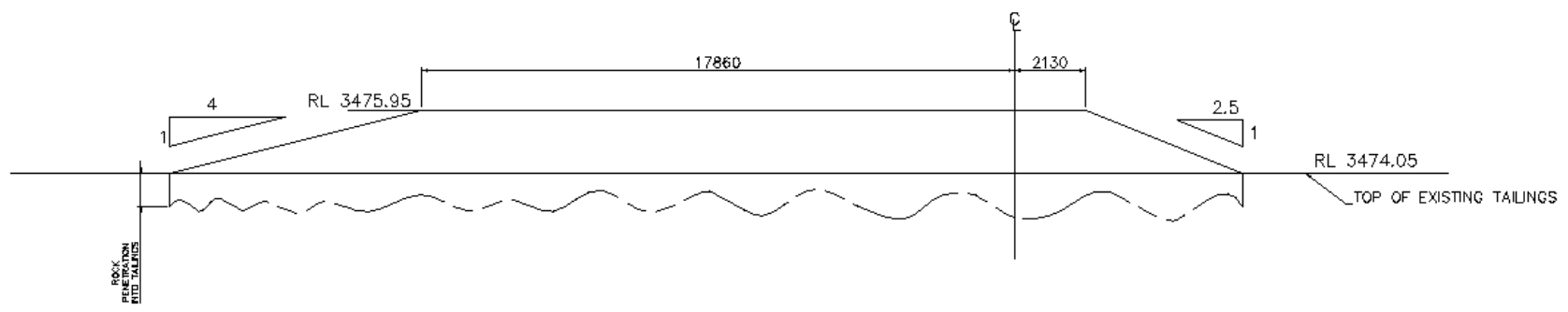

Figure 15 Final cross-section - groyne No. 9 (tail on the downstream side was not constructed)

Figures 16 and 17 show the mud wave developed in response to the end-dumping method and near completion of the groyne, respectively. Tails penetration can clearly be seen at the end of the groyne in Figure 16.

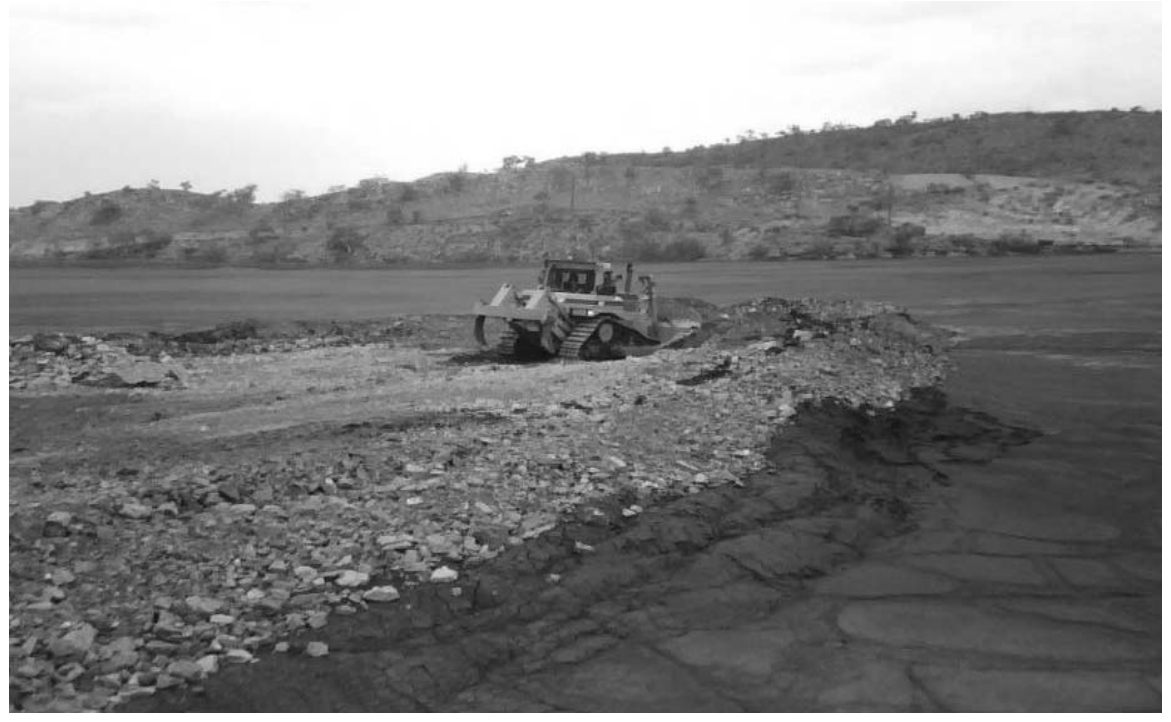

Figure 16 Mud wave ahead of D10

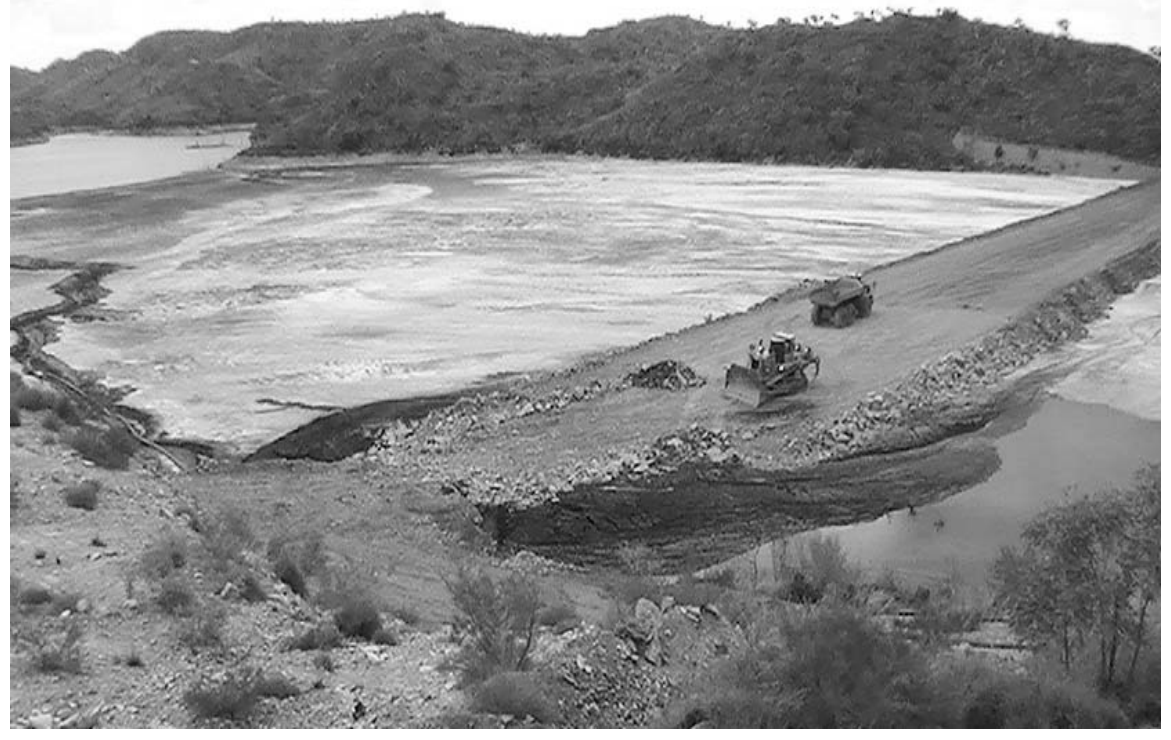

Figure 17 Groyne No. 9 near completion to full height 
The project was completed within 30 operational days at a cost of AU $\$ 598,843$. The cost of raising the groyne to ensure a stable foundation to work from increased the estimated Bill of Quantities (BOQ) listed in Table 3 by $166 \%$. The actual quantities are based on load sheets. The load sheets indicate that 3,000 trips at an estimated 30 tonnes per trip were placed at the groyne giving an estimated finished mass of 90,000 tonnes or $45,000 \mathrm{~m}^{3}$. This increase in the BOQ was due to the penetration of the ROM into tails. The cost to completion compares very favourably to the original estimates supplied to build the groyne to the original BOQ listed in Table 2. Following construction of the groyne No. 9 by the 'ice-breaker' method, no signs of instability were noted or observed indicating a stable condition.

\section{Discussions}

The numerical modelling showed that the rockfill embankment constructed by either layer-dumped or enddumping methods would not be stable in the absence of the rockfill penetration into the tailings to replace and/or displace the tailings, and ultimately improving the foundation of the rockfill embankment. Alternatively, additional support such as geotextile may be used; however in this case placing the geotextile was not practical due to the reason mentioned in Section 3.2.

Since the completion of the groyne by the end-dumping method, no evidence of instability was found. It was concluded that the foundation had been improved due to the rock penetration, and hence the stability condition of the groyne was not considered an issue. Therefore, apart from conventional surface monitoring no additional monitoring would be required. It should also be mentioned that improving the foundation reduces the potential of failure due to liquefaction. The liquefaction potential as reported by Soliman (2008) was undertaken based on the method presented by Youd et al. (2001). The method is understood to be considered the best practice. Simply, the method requires calculation of the cyclic stress ratio (CSR) induced by the earthquake and the cyclic resistance ratio (CRR) which is a function of the strength of the material susceptible to liquefaction. In general term, for the liquefaction to occur the CRR should be less than CSR. For illustration purpose, an attempt was made to demonstrate the effect of rock penetration on the factor of safety against liquefaction. Figure 18 shows the calculated factor of safety for three scenarios using one of the cone penetration tests which were previously carried out at tailings TSF No. 5. These scenarios were: no rockfill embankment, groyne No. 9 of $2.3 \mathrm{~m}$ with no rock penetration into the tailings and the groyne with $10 \mathrm{~m}$ rock penetration. The figure displays the factor of safety with depth below the bottom of the rock penetration zone. The figure illustrates a general trend of further increase of the factor of safety in case of the rock penetration indicating. This is considered a significant risk reduction when compared with the potential risk associated with raising the groyne by the up-stream construction which needs to be managed in both the short and the long term.

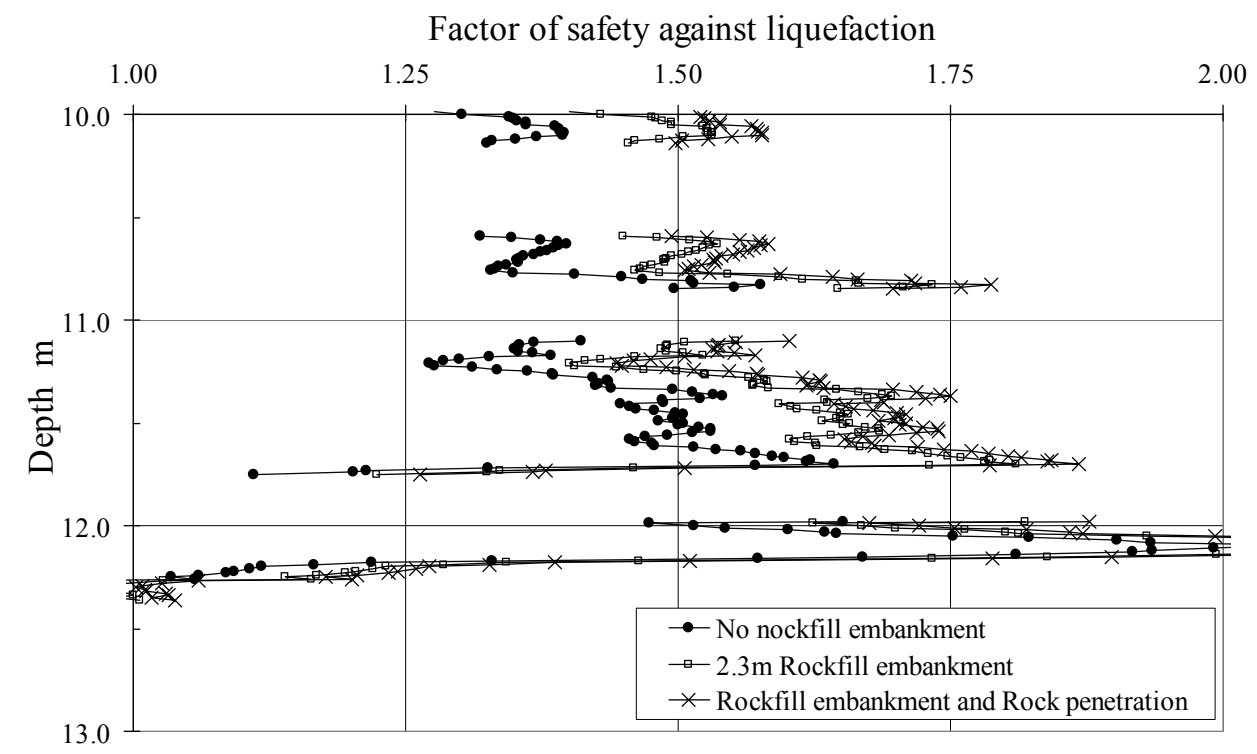

Figure 18 Illustration factor of safety against liquefaction 
In spite of the fact that displacing the tailings is certain and predicted to happen during construction by the end-dumping method as indicated by the formation of the 'mud wave', the displacement is controlled and can be managed safely. As a result, the risk of a sudden and/or catastrophic failure of the rockfill embankment is also eliminated.

\section{Conclusions}

Simple numerical modelling was developed to assist in understanding the performance of the tailings in response to the surcharge of the rockfill embankment. Various scenarios were analysed including modelling the most common rockfill construction methods named the layer-dumped and end-dumping methods. The modelling was based principally on: the in situ strength parameters of the tailings at tailings TSF No. 5, modelling a $35 \mathrm{~m}$ high embankment, $20 \mathrm{~m}$ thick tailings deposited on the bedrock and groundwater table at approximately $5 \mathrm{~m}$ below the tailings surface. For the layer-dumped and end-dump methods, the modelling indicated clearly that in the absence of the rockfill penetration into the tailings or additional support, maintaining the stability of the rockfill embankment cannot be achieved.

Additional modelling was carried out taking into account the rockfill penetration into the tailings. The results showed a stable embankment can be achieved provided that sufficient rockfill penetration will occur. For the geometry of the problem analysed, it is estimated that the rockfill will penetrate the entire thickness of the tailings and reach the in situ bedrock. 'Mud wave' will most certain take place during placement of the rockfill. It is anticipated that the tailings may heave up to approximately $5 \mathrm{~m}$. The wave may reach its peak at approximately 20-30 $\mathrm{m}$ from the toe of the embankment, then diminish gradually beyond this distance.

The end-dumping method reduces the risk of unexpected failure to as low as practically possible. This is due to the fact that the displacement of the tailings occurs during construction of the rockfill embankment, which is predictable, can be controlled and managed safely. The end-dumping method also improves the foundation. Therefore, the risk of a sudden and/or catastrophic failure is basically removed during the life of the project.

The cost of raising the groyne to ensure a stable working foundation increased the estimated BOQ listed in Table 3 by $166 \%$. This increase in the BOQ was due to the penetration of the ROM into tails. The cost to completion compares very favourably to the original estimates supplied to build the groyne to the original BOQ.

During and after construction of the groyne No. 9 by the 'ice-breaker' method, no signs of instability issues were noted or observed.

\section{Acknowledgements}

The authors would like to thank Xstrata Copper and Xstrata Zinc for permission to publish this paper.

\section{References}

Caldwell, J.A. (1985) Simplified Stability Analysis, in design of non-impounding mine waste dumps, M.K. McCarter (ed), The American Institute of Mining, Metallurgical and Petroleum Engineers, pp. 48-54.

Golder (2009) Groyne 9 design report, Golder Associates Report, unpublished.

Rocscinece (2005) Phase2 6.0 User's Manual, Rocscience Inc., Canada.

Soliman, A. (2008) MPV WRD TD5 - Tailings assessment, Internal report, Xstrata Zinc, Mt Isa, unpublished.

Soliman, A. (2010) Rockfill embankment on tailings numerical simulation, Internal memorandum, Xstrata Zinc, Mt Isa, unpublished.

Youd, T.L., Idriss, I.M., Andurus, R.D., Arango, I., Castro, G., Christian, J.T., Dobry, R., Finn, W.D.L., Harder, L.F., Haymes, M.E., Ishihara, K., Koester, J.P., Liao, S.S.C., Marcusson, W.F., Martin, G.R., Mitchell, J.K., Moriwaki, Y., Power, M.C., Robertson, P.K., Seed, R.B. and Stokoe, K.H. (2001) Liquefaction Resistance of Soils: Summary Report from the 1996 NCEER and 1998 NCEER/NSF Workshops on Evaluation of Liquefaction Resistance of Soils, Journal of Geotechnical and Geo-environmental Engineering, ASCE, Vol. 127, No. 10, pp. 817-833. 